$11-1-1982$

\title{
State Income Taxation of Multijurisdictional Corporations, Part II: Reflections on ASARCO and Woolworth
}

Walter Hellerstein

University of Georgia School of Law, wallyh@uga.edu

p bepress SSRN

\section{Repository Citation}

Walter Hellerstein, State Income Taxation of Multijurisdictional Corporations, Part II: Reflections on ASARCO and Woolworth (1982),

Available at: https://digitalcommons.law.uga.edu/fac_artchop/311

This Article is brought to you for free and open access by the Faculty Scholarship at Digital Commons @ University of Georgia School of Law. It has been accepted for inclusion in Scholarly Works by an authorized administrator of Digital Commons @ University of Georgia School of Law. Please share how you have benefited from this access For more information, please contact tstriepe@uga.edu. 


\section{STATE INCOME TAXATION OF MULTIJURISDICTIONAL CORPORATIONS, PART II: REFLECTIONS ON ASARCO AND WOOLWORTH}

Walter Hellerstein*

The first part of this Article, State Income Taxation of Multijurisdictional Corporations: Reflections on Mobil, Exxon, and H.R. 5076, did not contemplate a sequel. The Supreme Court's decisions last term in two state corporate income tax cases, however, created an irresistible opportunity to write one. The Court's opinions in $A S A R C O^{2}$ and Woolworth ${ }^{3}$ picked up where its opinions in Mobil $^{4}$ and Exxon ${ }^{5}$ left off. Yet the direction taken by these more recent decisions veers sharply from the course ostensibly set by their predecessors. This Article will consider the Court's latest pronouncements in this area in a continuing if quixotic effort to discover where they may be leading. After analyzing the Court's decisions in $A S A R C O$ and Woolworth against the background of the uniform state law from which they arose, the Article explores the framework of state income taxation of multijurisdictional corporations in the wake of these decisions.

\section{THE DeCisions IN $A S A R C O$ AND WOOLWORTH}

\section{A. The Federal Constitutional and State Statutory Background}

Most states impose a broad-based tax upon the income of corporations doing business within their borders. ${ }^{6}$ When the states apply such a tax to income generated by activities carried on across state lines, the strictures of the commerce and due process clauses compel

* Associate Professor of Law, University of Georgia. A.B. 1967, Harvard University; J.D. 1970, University of Chicago.-Ed.

1. Hellerstein, State Income Taxation of Multijurisdictional Corporations: Reflections on Mobil, Exxon, and H.R. 5076, 79 Mich. L. REv. 113 (1980).

2. ASARCO Inc. v. Idaho State Tax Commn., 102 S. Ct. 3103 (1982).

3. F. W. Woolworth Co. v. Taxation and Revenue Dept., 102 S. Ct. 3128 (1982).

4. Mobil Oil Corp. v. Commissioner of Taxes, 445 U.S. 425 (1980).

5. Exxon Corp. v. Department of Revenue, 447 U.S. 207 (1980).

6. 1 St. TAX Guide (CCH) 662 (June 1982). 
them to confine their taxing power to income fairly attributable to activities carried on within the state. ${ }^{7}$ As elaborated in the first installment of this Article, the Supreme Court in Mobil Oil Corp. v. Commissioner of Taxes ${ }^{8}$ and Exxon Corp. v. Department of Revenue ${ }^{9}$ examined these strictures in opinions that delineated the constitutional limitations on the state's power to include income in a corporation's apportionable tax base. In Mobil, the Court held that neither the due process nor commerce clause prohibited a state from including in the apportionable tax base of a nondomiciliary corporation the dividends it received from foreign subsidiaries and affiliates with which it was conducting a unitary business carried on in part in the taxing state. In Exxon, the Court held that neither the due process nor commerce clause prohibited a state from including in the apportionable tax base of a nondomiciliary corporation all of the operating income it derived from its unitary business carried on in part in the taxing state.

Mobil announced, and Exxon repeated, the fundamental proposition underlying both decisions: "[T]he linchpin of apportionability in the field of state income taxation is the unitary-business principle."10 "In accord with this principle," the Court declared in Mobil,

what appellant must show, in order to establish that its dividend income is not subject to an apportioned tax in Vermont, is that the income was earned in the course of activities unrelated to the sale of petroleum products in that State. 11

Because Mobil did not attempt to meet this burden, "Vermont was entitled to conclude that the dividend income's foreign source did not destroy the requisite nexus with in-state activities."12 The Court clearly indicated, however, that some dividend income remained beyond the reach of the states' tax power. ${ }^{13}$

In Exxon, the Court reiterated Mobil's assertion that "[t]he 'linchpin of apportionability' for state income taxation of an interstate enterprise is the "unitary-business principle," "14 and it repeated

7. See, e.g., Mobil Oil Corp. v. Commissioner of Taxes, 445 U.S. 425 (1980).

8. 445 U.S. 425 (1980).

9. 447 U.S. 207 (1980).

10. 445 U.S. at 439; see 447 U.S. at 223.

11. 445 U.S. at 439.

12. 445 U.S. at $439-40$.

13. We do not mean to suggest that all dividend income received by corporations operating in interstate commerce is necessarily taxable in each State where that corporation does business. Where the business activities of the dividend payor have nothing to do with the activities of the recipient in the taxing State, due process considerations might well preclude apportionability, because there would be no underlying unitary business.

445 U.S. at $441-42$.

14. 447 U.S. at 223 (citations omitted) (quoting Mobil, 445 U.S. at 439). 
that

[i]n order to exclude certain income from the apportionment formula, the company must prove that "the income was earned in the course of activities unrelated to the sale of petroleum products in that State." The court looks to the "underlying economic realities of a unitary business," and the income must derive from "unrelated business activity" which constitutes a "discrete business enterprise."15

After reviewing the facts, the Court concluded that Exxon's overall operations constituted a unitary business carried on in part in the taxing state. Exxon had failed to demonstrate that its separate functional departments were "discrete business enterprises."16 All of its operating income was, therefore, properly includable in its apportionable tax base.

Despite the critical importance the Court attributed to the unitary business principle in Mobil and Exxon, neither case compelled the Court to flesh out the concept. In Mobil, the taxpayer never addressed, and hence all but conceded, the unitary business issue because of its (ultimately misguided) belief that "the existence or nonexistence of a unitary relationship between Mobil and corporations which paid the . . . dividends at issue is irrelevant."17 In Exxon, the unitary business issue presented little difficulty because the Court was confronted with a vertically integrated enterprise where products flowed from wellhead to gas pump, where services were readily transferred between divisions, and where there was "an umbrella of centralized management and controlled interaction." 18

In its latest term, by contrast, the Court faced much thornier unitary business issues that all parties squarely addressed. ${ }^{19} A S A R C O$ Inc. v. Idaho State Tax Commission ${ }^{20}$ involved a constitutional challenge to Idaho's power to include within a nondomiciliary corporation's apportionable tax base income from intangibles (dividends, interest, and capital gains) received from subsidiary corporations which, unlike the parent, did no business in the taxing state. $F W$. Woolworth Co. v. Taxation and Revenue Department ${ }^{21}$ involved a constitutional challenge to New Mexico's power to include within a nondomiciliary corporation's apportionable tax base income from

15. 447 U.S. at 223-24 (citations omitted) (quoting Mobil, 445 U.S. at 439, 441, 442).

16. 447 U.S. at 224 (quoting Mobil, 445 U.S. at 439).

17. Appellant's Reply Brief at 4, Mobil; see Hellerstein, supra note 1, at 121-30.

18. 447 U.S. at 224; see Hellerstein, supra note 1, at 141-51.

19. In addition to the parties, numerous atmici curiae filed briefs in the two cases, including the Multistate Tax Commission, whose construction of UDITPA was implicitly at issue.

20. 102 S. Ct. 3103 (1982).

21. 102 S. Ct. 3128 (1982). 
intangibles (dividends) received from subsidiary corporations which, unlike the parent, did no business in the taxing state. ${ }^{22}$ The underlying question was no longer whether income derived from constituent parts of a vertically integrated enterprise was includable in its apportionable tax base by the state in which the enterprise sold its products - the essential unitary business issue in both Mobil and Exxon. Rather, the question was whether income received by a nondomiciliary enterprise doing business in the taxing state from corporations with which it was not vertically integrated was includable in the enterprise's apportionable tax base when it held substantial ownership interests in and enjoyed a variety of working relationships with such corporations. This basic question raised a host of related issues: What were the precise criteria among the many commonly advanced $^{23}$ and beyond those hitherto offered by the Court ${ }^{24}$ for determining whether a business was unitary? What were the facts, short of vertical integration, that carry special weight in making such a determination? In the context of income from intangibles, is it the relationship between the payor and payee's activities that governs the unitary business issue or can the payee's own relationship to the intangibles, as distinguished from its relationship to the underlying corporate entities, be considered part of the payee's unitary business justifying inclusion of the income in its apportionable tax base? And if the income is apportionable, must some adjustment be made in the formula employed to apportion the income to the taxing state in order to comply with the due process requirement that "the income attributed to the State for tax purposes must be rationally related to 'values connected with the taxing State' "?25

The constitutional conflicts in ASARCO and Woolworth originated in analogous disputes between the parties under state law: Like a majority of the states imposing corporate income taxes, Idaho and New Mexico have sought to discharge their constitutional obligation to tax only income fairly attributable to activities carried on within the state by enacting the Uniform Division of Income for Tax Purposes Act (UDITPA). ${ }^{26}$ UDITPA provides rules for determining

22. Woolworth also raised the question whether New Mexico could constitutionally include in Woolworth's apportionable tax base a sum Woolworth was required to report as income on its federal tax return in order to claim a foreign tax credit with respect to taxes paid by its foreign subsidiaries. See text at notes 125-27 infra.

23. See Hellerstein, supra note 1, at 149.

24. Id. at 148-51.

25. Moorman Mfg. Co. v. Bair, 437 U.S. 267, 273 (1978); see Hellerstein, supra note 1, at 127-30.

26. Uniform Division of Income for Tax Purposes Act, 7A U.L.A. 91 (1978) [hereinafter cited without cross-reference as UDITPA]; IDAHo CoDE § 63-3027 (Supp. 1982); N.M. STAT. 
the portion of a multijurisdictional corporation's income that a state may tax.

UDITPA solves the problem of dividing a multijurisdictional corporation's income among the states either by apportioning it among the states by formula or by allocating it to a particular state. ${ }^{27}$ Whether income is apportionable or allocable depends on the statutory distinction between "business income" ("income arising from transactions and activity in the regular course of the taxpayer's trade or business") ${ }^{28}$ and "non-business income" ("all income other than business income"). ${ }^{29}$ Business income is apportionable; nonbusiness income is allocable. Under UDITPA, business income is apportioned by the familiar three-factor formula that apportions to the taxing state a percentage of the taxpayer's income equal to the average of three ratios: the ratio of the taxpayer's in-state property to its total property, of its in-state payroll to its total payroll, and of its instate receipts to its total receipts. ${ }^{30}$ Nonbusiness income is allocated to the particular state or states that UDITPA designates for specific types of nonbusiness income. ${ }^{31}$

The constitutional controversies in $A S A R C O$ and Woolworth whether the income at issue arose out of a unitary business conducted in the taxing state - mirrored the state law questions they raised under UDITPA - whether the income in dispute was business or nonbusiness income. While the Supreme Court necessarily limited its decisions to the federal constitutional questions, their implications are likely to be reflected in state court and agency interpretations of UDITPA where these issues generally are first confronted. It is therefore appropriate to begin the discussion of these cases with a brief description of the state administrative and judicial proceedings, which focused on UDITPA.

ANN. \$\$ 7-4-1 to -21 (Replacement Pamphlet 1981); see 7A U.L.A. 10 (Supp. 1982); ST. \& Loc. TAX SERv. (P-H) (All States Unit) II 1046 (1979).

27. As to the distinction between specific allocation and formulary apportionment and other general considerations relating to the methods employed by the states for dividing the income of multijurisdictional corporations, see Hellerstein, supra note 1, at 116-18.

28. UDITPA § 1; IdAHo CODE § 63-3027(a)(1) (Supp. 1982); N.M. STAT. ANN. § 7-4-2(A) (Replacement Pamphlet 1981).

29. UDITPA § 1(e); IDAHO CODE § 63-3027(a)(4) (Supp. 1982); N.M. STAT. ANN. § 7-4 2(D) (Replacement Pamphlet 1981).

30. UDITPA $\$ \$$ 9-17; IdaHo CodE $\$ \$ 63-3027(i)-(q)$ (Supp. 1982); N.M. STAT. ANN. $\$ \$ 7-$ 4-10 to -18 (Replacement Pamphlet 1981).

31. UDITPA $\$ \$ 4-8$; IDAHO CODE $\$ \$ 63-3027(d)-(h)$ (Supp. 1982); N.M. STAT. ANN. \$§ 74-5 to -9 (Replacement Pamphlet 1981). 


\section{B. The State Administrative and Judicial Proceedings}

\section{The Proceedings Below in ASARCO}

ASARCO, the erstwhile American Smelting and Refining Company, engages in the business of mining, smelting, refining, and selling nonferrous metals. It is incorporated in New Jersey, maintains its headquarters and commercial domicile in New York, and conducts business in many states and abroad. ASARCO's principal activity in Idaho is the mining of silver. ASARCO's other activities in the state include the mining of lead and zinc, the operation of a regional administrative office, and the sale of secondary materials.

During the years at issue, 1968 through 1970, ASARCO received substantial income from its ownership and sale of intangible property. The controversy between the parties focused on the receipt of such income from ASARCO's interests in five other corporations, none of which conducted any business in Idaho: M.I.M. Holdings, Ltd., which was 53 percent owned by ASARCO, engaged in the production and processing of nonferrous metals in Australia and England; General Cable Corp., which was 34 percent owned by ASARCO, manufactured cable; Revere Copper and Brass, Inc., which was 34 percent owned by ASARCO, manufactured copper products; ASARCO Mexicana, S.A., which was 49 percent owned by ASARCO, carried on in Mexico the same general type of business that ASARCO carries on in the United States; and Southern Peru Copper Corp., which was 51.5 percent owned by ASARCO, produced and smelted copper in Peru. ASARCO received dividends from all five corporations. It received interest on Revere's convertible debentures, on a note acquired in connection with an earlier sale of Mexicana stock, and on a note acquired in connection with a 1970 sale of General Cable stock. It received capital gains from the sale of General Cable and M.I.M. stock. The amounts involved averaged over $\$ 50$ million on an annual basis.

In filing its Idaho tax returns for the years in question, ASARCO took the position that none of its income from intangibles should be included in its apportionable tax base..$^{32}$ While conceding that its operating income should be apportioned as business income under UDITPA, ${ }^{33}$ ASARCO believed that its income from intangibles, in

32. Jurisdictional Statement at 7, ASARCO Inc. v. Idaho State Tax Commn, 102 S. Ct. 3103 (1982).

33. For the tax year 1968, ASARCO originally took the position that its income should be attributed to the state by separate accounting. Joint Appendix at 26a, ASARCO Inc. v. Idaho -State Tax Commn., 102 S. Ct. 3103 (1982); see Hellerstein, supra note 1, at 117. It subsequently agreed to apportion its operating income for that year, consistently with its treatment 
particular its dividend, interest, and capital gain income, ${ }^{34}$ should be treated as nonbusiness income under UDITPA and allocated to its commercial domicile, New York. ${ }^{35}$ ASARCO based its stance on the view that its income from intangibles failed to satisfy Idaho's version of UDITPA's definition of business income:

"Business income" means income arising from transactions and activity in the regular course of the taxpayers' trade or business and includes income from the acquisition, management, or disposition of tangible and intangible property when such acquisition, management, or disposition constitute integral or necessary parts of the taxpayers' trade or business operations. ${ }^{36}$

In 1971, the Multistate Tax Commission (MTC) completed a joint audit of ASARCO's tax returns for the years at issue on behalf of Idaho and five other states. ${ }^{37}$ The MTC auditor recommended, among other things, ${ }^{38}$ that the dividends, interest, and capital gains received by ASARCO from the five corporations mentioned above

of such income for 1969 and 1970. See Jurisdictional Statement at 7 n.8; Joint Appendix at 26 .

34. ASARCO also had income from royalities which it treated as nonbusiness income. Joint Appendix at 26a.

35. See UDITPA $\S 6(c)$, 7; IDAHo CODE § 63-3027(f)(3), (g) (Supp. 1982).

36. IDAKO CODE \$63-3027(a)(1) (Supp. 1982). UDITPA's definition of "business income," UDITPA \& 1(a), differs from the Idaho definition in two respects: it does not contain the phrase "or necessary" after "integral" in the sentence quoted in the text; nor does it contain the following sentence, which appears in the Idaho Code, creating a presumption that certain income from intangibles is business income:

Gains or losses and dividend and interest income from stock and securities of foreign or domestic corporations shall be presumed to be income from intangible property, the acquisition, management, or disposition of which constitute an integral part of the taxpayers' trade or business; such presumption may only be overcome by clear and convincing evidence to the contrary.

IDAHO CODE § 63-3027(a)(1) (Supp. 1982).

37. Multistate Tax Commission Audit Report, reprinted in Joint Appendix 83a. The Multistate Tax Commission is the administrative agency of the Multistate Tax Compact, of which Idaho is a member. IDAHO CODE § 63-3701 (1976). Article VIII of the Compact authorizes the MTC to perform interstate audits on behalf of member states. The constitutionality of the Compact and its joint audit provisions was upheld in United States Steel Corp. v. Multistate Tax Commn., 434 U.S. 452 (1978).

38. The MTC auditor recommended that ASARCO and six of its wholly owned subsidiaries be combined and treated as a single corporation for tax purposes. Multistate Tax Commission Audit Report, reprinted in Joint Appendix at 87a. The auditor justified his recommendation by pointing to ASARCO's majority ownership of each of the subsidiaries, its conduct of a vertically integrated nonferrous metals business with them, its maintenance of interlocking officers and directors with the subsidiaries, the flow of products among the companies as evidenced by intercompany sales, and the flow of services among the companies. Multistate Tax Commission Audit Report, reprinted in Joint Appendix at 88a-91a. As a result of this combined treatment, the dividends that the subsidiaries paid to ASARCO would be disregarded as intracompany transfers, and the collective operating income of the combined group of corporations would be apportioned on the basis of a formula that reflected the property, payroll, and receipts factors of the entire group. On the combined report, see Hellerstein, supra note 1 , at 123 and sources cited therein. 
be classified as business income and apportioned under UDITPA. ${ }^{39}$ The Idaho State Tax Commission embraced this recommendation, concluding that the income in question was properly classified as business income under UDITPA because it was "received in the regular course of [ASARCO's] trade or business and arose from transactions and activities in the regular course of such trade or business."40 The state trial court overturned the state tax commission's determination. ${ }^{41}$ It found instead that the income should be allocated to New York, ASARCO's commercial domicile, because

[t] he income described does not come from property or activities which is [sic] an integral part of the taxpayer's trade or business. . . . It appears to the court that if the dividend income from other corporations is an integral part of the business of the plaintiff that they should be unitized [i.e., combined] and all matters considered and if they are not that the income is not business income but is nonbusiness income. ${ }^{\mathbf{4 2}}$

The Supreme Court of Idaho in turn reversed the district court and held that the disputed income ASARCO received from the five corporations in question was business income apportionable under UDITPA. ${ }^{43}$ It rebuffed constitutional objections to this conclusion, dismissing challenges both to the apportionability of the income as well as to the formula employed to apportion it. On ASARCO's appeal of this determination, the Supreme Court of the United States vacated the state court's judgment and remanded the case "for further consideration in light of Mobil Oil Corp. v. Commissioner of Taxes . . . "44 On remand, the Idaho Supreme Court reinstated its original opinion in a brief order which explained only that "it is the conclusion of this Court that our prior opinion and order are consistent with both Mobil Oil and the more recent decision in Exxon

39. Multistate Tax Commission Audit Report, reprinted in Joint Appendix at 92a-96a. Under UDITPA, ASARCO's business income, including its business income from intangibles, would be apportioned on the basis of a formula that reflected the property, payroll, and receipts factors of ASARCO. The formula would not take account of the property, payroll, or receipts factors of the corporations from which ASARCO derived its business income from intangibles. This separate company approach to the taxation of income from intangibles is to be contrasted with the combined approach. See note 38 supra; Hellerstein, supra note 1, at 123-24.

40. In re Petition for Redetermination of Income Tax Deficiency by American Smelting \& Refining Company (ASARCO), reprinted in Jurisdictional Statement app. 46a, 53a-54a, 58a.

41. American Smelting and Refining Co. v. Idaho State Tax Commn., No. 53182 (Dist. Ct. of Ada County, Nov. 13, 1975), reprinted in Jurisdictional Statement app. at 36a.

42. Jurisdictional Statement app. at 37a.

43. American Smelting and Refining Co. v. Idaho State Tax Commn., 99 Idaho 924, 592 P.2d 39 (1979).

44. ASARCO Inc. v. Idaho State Tax Commn., 445 U.S. 939 (1980) (mem.), vacating and remanding 99 Idaho 924, 592 P.2d 39 (1979). 
Corp. v. Wisconsin Dept. of Revenue . . ."45 ASARCO once again appealed to the Supreme Court, which noted probable jurisdiction. ${ }^{46}$

\section{The Proceedings Below in Woolworth}

F. W. Woolworth Company engages in the general retail merchandise business throughout the United States, Puerto Rico, and the Virgin Islands. It purchases a variety of consumer goods and sells them at retail through Woolworth and Woolco stores. 47 Its principal place of business and commercial domicile are located in New York, where it is incorporated. During the tax year at issue (1976-77), Woolworth's retail sales in New Mexico exceeded \$13 million.

Woolworth, like ASARCO, received substantial income from the ownership of intangible property. The dispute centered on the $\$ 40$ million in dividends that Woolworth received from four of its foreign subsidiaries:48 F. W. Woolworth G.m.b.H., a wholly owned German subsidiary; F. W. Woolworth, Ltd., a wholly owned Canadian subsidiary; F. W. Woolworth Co., S.A. de C.V. Mexico, a wholly owned Mexican subsidiary; and F. W. Woolworth Co., Ltd., a 52.7 percent owned English subsidiary. These subsidiaries conduct the same general type of business in their respective countries as Woolworth conducts in the United States.

In filing its New Mexico tax return for the year in question, Woolworth, like ASARCO, took the position that none of its dividends should be included in its apportionable tax base. ${ }^{49}$ Like ASARCO, Woolworth conceded that its operating income should be apportioned under UDITPA but insisted that its dividend income should be classified as nonbusiness income under UDITPA and allo-

45. American Smelting and Refining Co. v. Idaho State Tax Commn., 102 Idaho 38, 624 P.2d 946 (1981).

46. ASARCO Inc. v. Idaho State Tax Commn., 102 S. Ct. 87 (1981) (mem.).

47. On September 24, 1982, Woolworth announced that it would close all of its 336 Woolco discount stores in early 1983 because of persistent losses from their operations. N.Y. Times, Sept. 25, 1982, at 21, col. 3.

48. In addition, the parties disagreed over the appropriate treatment of Woolworth's dividend "gross-up" required to be reported as federal taxable income in order to receive credit for foreign taxes paid by foreign subsidiaries, I.R.C. $\$ \S 78,901$ (a), 902(a) (1976); see note 22 supra, as well as its treatment of a foreign exchange gain from a hedging transaction in British pounds. The "gross-up" issue will be discussed separately below. See text at notes 125-27 infra. The foreign currency issue, which was not addressed by either of the state appellate courts and was not raised by Woolworth in the Supreme Court, will be ignored.

49. Jurisdictional Statement at 6-7, F. W. Woolworth Co. v. Taxation and Revenue Dept., 102 S. Ct. 3128 (1982); see text at note 32 supra. 
cated to its commercial domicile, New York..$^{50}$ On audit, the New Mexico Taxation and Revenue Department, like the Idaho State Tax Commission, classified the taxpayer's dividend income as business income apportionable under UDITPA. ${ }^{51}$

In the state courts, the parallelism between the Woolworth and $A S A R C O$ cases continued. The first judicial tribunal to consider the issue, the New Mexico Court of Appeals, determined that the dividend income was not apportionable business income under UDITPA because in its judgment there was, among other things, "no indication that the income from Woolworth's long-standing investments [in its subsidiaries] was used either in taxpayer's unitary domestic business or in its business conducted in New Mexico."52 The Supreme Court of New Mexico, like the Supreme Court of Idaho, overturned the lower state court ruling. ${ }^{53}$ It found "substantial evidence" to support the Revenue and Taxation Department's determination that the dividends were business income under UDITPA because "[t]he income arose from activities of Woolworth in the regular course of its business," 54 "[t]he income was acquired and managed as an integral part of its regular business operations,"ss and "[t]he purpose for acquiring and holding the stock is related to its business operations." 56 The court disposed of constitutional objections to its conclusion relying on the Supreme Court's opinions in Mobil and Exxon. ${ }^{57}$ When Woolworth appealed, the Court noted probable jurisdiction and set the case for oral argument in tandem with $A S A R C O .58$

\section{The Supreme Court's Opinions}

The Supreme Court reversed in both cases and held in two six-tothree decisions that the due process clause barred Idaho and New Mexico from including any of the disputed income in the recipients'

50. Jurisdictional Statement at 6-7; N.M. Stat. ANN. $\$ \S 7-4-8$, -10 (Replacement Pamphlet 1981); see text at notes 33-36 supra.

51. In re Liability of F. W. Woolworth Co., reprinted in Jurisdictional Statement 30a-37a; see text at note $\mathbf{4 0}$ supra.

52. F. W. Woolworth Co. v. Bureau of Revenue, 95 N.M. 542, 545, 624 P.2d 51, 54 (Ct. App. 1979) (citations omitted); see text at notes 41-42 supra.

53. Taxation and Revenue Dept. v. F. W. Woolworth Co., 95 N.M. 519, 624 P.2d 28 (1981); see text at note 43 supra.

54. 95 N.M. at 526,624 P.2d at 35 .

55. 95 N.M. at 526, 624 P.2d at 35.

56. 95 N.M. at 526, 624 P.2d at 35.

57. 95 N.M. at 526-29, 624 P.2d at 35-38.

58. 102 S. Ct. 86 (1981). 
apportionable tax bases. ${ }^{59}$ Taken at face value, the Court's opinions hardly warrant extended comment. In its view, the Court was merely applying settled constitutional principles so recently articulated in Mobil and Exxon to two sets of facts that happened to require a different result. ${ }^{60}$ Despite the Court's disclaimers, however, several factors justify a more searching examination of the Court's opinions and their implications. First, there is considerable question whether the Court's opinions in $A S A R C O$ and Woolworth faithfully adhere to the teachings of Mobil and Exxon. Second, whether they do or not, the $A S A R C O$ and Woolworth opinions are important in their own right as statements of the prevailing constitutional standards in this area. Third, the opinions will undoubtedly have a significant impact on state administrative and judicial interpretations of UDITPA, a development that deserves separate attention. Finally, apart from any doctrinal import that the cases may have, they suggest a judicial attitude toward state division-of-income rules at odds with the attitude underlying its decisions in Mobil and Exxon. If the Court's most recent opinions in this area accurately reflect its current mood, the institutional consequences are likely to be strikingly different from those one might have anticipated from its opinions in Mobil and Exxon. All of these matters will be taken up in the discussion that follows.

\section{The Supreme Court's Opinion in ASARCO}

a. The doctrinal issue. After dutifully reciting the principles set forth in Mobil and Exxon, the Court described its task as determining whether, on the record before it, "ASARCO . . . has succeeded, where the taxpayers in Mobil and Exxon failed, in proving that the dividend payors at issue are not part of its unitary business, but rather are 'discrete business enterprises.' "61 By thus stating the issue, the Court disposed of the critical doctrinal question in the case: whether the out-of-state payor must engage in a unitary business with the nondomiciliary in-state payee to justify a state's inclusion in the payee's apportionable tax base of income from intangibles it receives from the payor, as ASARCO contended; or whether a state may justifiably include income from intangibles in the nondomicil-

59. ASARCO Inc. v. Idaho State Tax Commn., 102 S. Ct. 3103 (1982); F. W. Woolworth Co. v. Taxation and Revenue Dept., 102 S. Ct. 3128 (1982). Justice Powell wrote both majority opinions; Justice O'Connor, joined by Justices Blackmun and Rehnquist, wrote both dissenting opinions; Chief Justice Burger wrote a brief concurring opinion in $A S A R C O$.

60. See, e.g., ASARCO, 102 S. Ct. at 3114 n.22, 3116 n.24.

61. 102 S. Ct. at 3111. 
iary payee's apportionable tax base so long as the intangibles themselves are used in the payee's unitary business, regardless of the underlying functional relationship between the out-of-state payor and the in-state payee, as Idaho asserted.

Neither the vague command of the due process clause nor the Court's opinions construing it spoke clearly to this issue. The due process clause required both a minimal connection between the activities of an interstate business and the taxing state as well as a rational relationship between the income attributed to the state and the intrastate activities of the business. ${ }^{62}$ The unitary business principle embodied the first limitation. The existence of a unitary business establishes the minimum nexus that a state must have with the outof-state activities of a multijurisdictional business in order to justify the state's taxing an apportioned share of all of the business income, for if a multijurisdictional business is unitary the state has some connection with all of it.63 The Court's decisions involving the unitary business principle certainly permitted the apportionment of intangibles ${ }^{64}$ and the income therefrom, ${ }^{65}$ as Idaho demonstrated. ${ }^{66}$ Yet they did not establish the proposition for which they were offered - that the due process clause's criterion for apportionability of income from intangibles is satisfied by 'the fact that ASARCO's acquisition, management and disposition of these intangible assets were regular parts of ASARCO's own unitary business . . . ."67 None of the cases cited by Idaho involved the apportionment of income received from payors with which the payee was not functionally integrated. By the same token, while the Court's opinion in Mobil had approved the apportionment of income from intangibles received from payors that were functionally integrated with the

62. Mobil Oil Corp. v. Commissioner of Taxes, 445 U.S. 425, 436-37 (1980).

63. See Hellerstein, supra note 1, at 121-27. At one point in its opinion in ASARCO, the Court seems to suggest that in the absence of a unitary business, there can be no rational relationship between the income attributed to the state and the intrastate values of an enterprise. $102 \mathrm{~S}$. Ct. at 3115. This may be true, but it is not terribly relevant. Once it has been determined that no unitary business (i.e., no minimal connection) exists justifying apportionment of the income in question, inquiry into the rational relationship issue is unnecessary. On the other hand, the determination that a business is unitary, thus justifying apportionment of the income in question, leaves very much alive the issue whether the income is being apportioned in a manner that satisfies the due process clause's rational relation requirement. See Hellerstein, supra note 1, at 127-30.

64. See, e.g., Adams Express Co. v. Ohio State Auditor, 165 U.S. 194 (1897).

65. See, e.g., Mobil Oil Corp. v. Commissioner of Taxes, 445 U.S. 425 (1980). (1982).

66. Brief for Appellee at 9-17, ASARCO Inc. v. Idaho State Commn., 102 S. Ct. 3103

67. Brief for Appellee at 9. 
payee, ${ }^{68}$ one would have been hard-pressed to derive from Mobil the proposition advanced by ASARCO that functional integration between payor and payee is the sina qua non of apportionability of income received by the latter from the former. 69

Understandably, then, the Court in $A S A R C O$ paid scant attention to its precedents in rejecting the contention that income from intangibles may be apportioned so long as they contribute to the payee's own unitary business carried on in part in the taxing state. Characterizing Idaho's position as having "corporate purpose ... define unitary business,"70 the Court invoked the internal logic of the unitary business principle itself in refuting it:

This definition of unitary business would destroy the concept. The business of a corporation requires that it earn money to continue operations and to provide a return on its invested capital. Consequently all of its operations, including any investment made, in some sense can be said to be "for purposes related to or contributing to the [corporation's] business." When pressed to its logical limit, this conception of the "unitary business" limitation becomes no limitation at all. When less ambitious interpretations are employed, the result is simply arbitrary. ${ }^{71}$

The Court thus repudiated Idaho's argument that use of an intangible asset in a taxpayer's own unitary business makes income from the asset apportionable.

It is not clear, however, to what extent the Court embraced ASARCO's contention that functional integration between payor and payee is a prerequisite to the apportionability of income from intangibles received by a nondomiciliary payee. Statements in the Court's opinion suggest, at least by negative inference, that functional integration between payor and payee along with centralized management and economies of scale are central to its conception of a unitary business for purposes of determining the apportionability of income from intangibles. ${ }^{72}$ The Court's analysis of the facts in the case, ${ }^{73}$ moreover, lends additional credence to the view that the underlying relationship between the activities of the payor and the payee circumscribes the scope of a unitary business in the context of income from intangibles. Furthermore, this is the way the dissent

68. Or, more accurately, from payors whose lack of functional integration with the payee the taxpayer had failed to prove.

69. See Brief for Appellant at 13-18, ASARCO Inc. v. Idaho State Tax Commn., $102 \mathrm{~S}$. Ct. 3103 (1982).

70. $102 \mathrm{~S} . \mathrm{Ct}$. at 3114 (emphasis in original).

71. $102 \mathrm{~S}$. Ct. at 3114 (emphasis in original) (footnote omitted).

72. $102 \mathrm{~S}$. Ct. at 3115-16.

73. $102 \mathrm{~S}$. Ct. at 3111-13; see text at notes 79-92 infra; see also F. W. Woolworth Co. v. Taxation and Revenue Dept., 102 S. Ct. 3128, 3134-39 (1982). 
reads the majority's opinion, which it accuses of substituting an "oversimplified test of active operational control"74 and functional

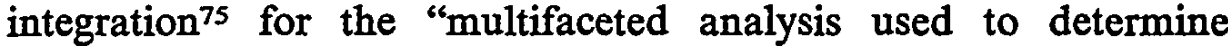
whether the businesses in Mobil Oil and Exxon were unitary."76 On this understanding of the Court's opinion, it would follow that only when the underlying business enterprises exhibit features of functional integration, centralized management, or economies of scale may income from intangibles be apportioned by a nondomiciliary state inasmuch as the unitary business principle is the "linchpin of apportionability in the field of state income taxation."77

The Court, however, may not have intended to adopt ASARCO's position without qualification. Despite the restrictive approach to apportionability that emerges from $A S A R C O$, language in the Court's opinion can be construed as accommodating a more expansive approach should the Court be persuaded to move in that direction. ${ }^{78}$ Whether the Court will adopt such an approach is likely to depend on its perception of the facts before it, a matter to which we now turn.

b. The factual issues. The Court's decision in $A S A R C O$ may well have been informed more by its perception of the facts than by its commitment to any particular definition of a unitary business. Indeed, one suspects that the Court would have found that the due process clause barred inclusion of the disputed income in ASARCO's apportionable tax base even if it had construed the unitary business principle more broadly for purposes of apportioning income from intangibles. In stressing that none of the five payor corporations in question was conducting a unitary business with ASARCO, the Court referred to trial court findings that "ASARCO's stock investments were 'not integral to nor a necessary part of [ASARCO's] business operation," "79 that ASARCO "has never been required to utilize its stock as security for borrowing of

74. $102 \mathrm{~S}$. Ct. at 3123 (O'Connor, J., dissenting).

75. 102 S. Ct. at 3119 (O'Connor, J., dissenting).

76. $102 \mathrm{~S}$. Ct. at 3123 (O'Connor, J., dissenting).

77. Mobil Oil Corp. v. Commissioner of Taxes, 445 U.S. 425, 439 (1980).

78. For example, the Court observed that "the application of the unitary-business principle requires in each case a careful examination both of the way in which the corporate enterprise is structured and operates, and of the relationship with the taxing state." $102 \mathrm{~S}$. Ct. at 3115 n.22. Inasmuch as future cases will bring before the Court corporate enterprises with structures, operations, and relationships to the taxing state different from those addressed in ASARCO, the Court is plainly leaving the door open for further refinement of its view of the unitary business concept.

79. $102 \mathrm{~S}$. Ct. at 3114 n.21 (quoting Jurisdictional Statement app. at 44a). 
working capital, acquiring stock or securities in other companies, or to support any bond issues," 80 and that "ASARCO was found to have 'sufficient cash flow from mining to provide operating capital for all mining operations without reliance upon cash flow from . . . income from intangibles.' "81 These facts would have supported a determination that ASARCO's income from the payor corporations was not apportionable even if the Court had articulated a unitary business principle encompassing ASARCO's use of intangible assets, such as working capital, that were integrally related to ASARCO's unitary business.

The Court never suggested, however, that it had this point in mind in its review of the facts in $A S A R C O$. Instead, it focused on the functional and managerial relationships between the payor corporations and ASARCO in determining the apportionability of the dividends, interest, and capital gains in question. Southern Peru, which was 51.5 percent owned by ASARCO, presented the "closest question."82 Although Southern Peru sold ASARCO 35 percent of its output and was potentially subject to its control, the Court, after examining the details of management contracts, cited trial court findings and evidence to the effect that ASARCO did not "control Southern Peru in any sense of that term." 83 It therefore concluded that "ASARCO's Idaho silver mining and Southern Peru's autonomous business are insufficiently connected to permit the two companies to be classified as a unitary business." 84

The Court likewise concentrated its attention on the functional and managerial links between the remaining out-of-state corporations and ASARCO in concluding that "the relationship of each of the other four subsidiaries to ASARCO falls far short of bringing any of them within its unitary business."85 M.I.M., which was 52.7 percent owned by ASARCO, failed the test because it was never actually controlled ${ }^{86}$ by ASARCO, operated "entirely independently

80. $102 \mathrm{~S}$. Ct. at $3114 \mathrm{n} .21$ (quoting Jurisdictional Statement app. at $41 \mathrm{a}$ ).

81. $102 \mathrm{~S}$. Ct. at $3114 \mathrm{n} .21$ (quoting Jurisdictional Statement app. at 41a).

82. 102 S. Ct. at 3111 .

83. 102 S. Ct. at 3112 (quoting Transcript of Proceedings in the District Court, reprinted in Joint Appendix 12la). Southern Peru's managing board was composed of thirteen directors, six of them named by ASARCO, six by the other shareholders, and the thirteenth by. either the first twelve directors or unanimous agreement of the shareholders.

84. 102 S. Ct. at 3112.

85. 102 S. Ct. at 3112 .

86. The Court acknowledged that ASARCO had the "control potential to manage M. I. M." 102 S. Ct. at 3113. 
of and ha[d] minimal contact with" 87 ASARCO, and sold ASARCO only 1 percent of its output. General Cable and Revere Copper, which were 34 percent owned by ASARCO, were not unitary with ASARCO because the intercompany purchases and sales never exceeded 6 percent of the totals involved, 88 and "[n]either Revere's nor General Cable's management seeks direction or approval from ASARCO on operational or other management decisions."89 Finally, ASARCO Mexicana, which was 49 percent owned by ASARCO, was not engaged in a unitary business with ASARCO because there were only "insignificant" intercompany sales during the years in question ${ }^{90}$ and Mexicana "operate[d] independently of [ASARCO]."91

In sum, because an examination of ASARCO's functional and managerial relationship with the out-of-state payors demonstrated to the Court's satisfaction that they were not engaged in a unitary business with ASARCO in the taxing state, the Court concluded that, under the due process clause, none of ASARCO's income from intangibles derived from its interests in these payors was apportionable. ${ }^{92}$

c. Concluding observations. Three further points warrant consideration before we conclude the discussion of the Court's opinion in $A S A R C O$. First, the Court's treatment of the question whether ASARCO and its subsidiaries engaged in a unitary business established no bright lines for resolving this issue in the future. The Court did, to be sure, reiterate and emphasize the guiding principles in its opinion. No less than six times did the Court remind us in $A S A R C O$ that proof of "discrete business enterprise" conducted by the out-ofstate payor will preclude the apportionability of dividends, interest, and capital gains by the state in which a nondomiciliary payee conducts its business; 93 and the Court four times repeated the admoni-

87. 102 S. Ct. at 3113 (quoting Findings and Conclusions of the State District Court, reprinted in Jurisdictional Statement app. at 43a).

88. See 102 S. Ct. at 3113 n.19.

89. 102 S. Ct. at 3113 (footnote omitted) (citing Transcript of Proceedings in the District Court, reprinted in Joint Appendix 121a, 137a).

90. See 102 S. Ct. at 3113 n.21.

91. $102 \mathrm{~S}$. Ct. at 3113 (quoting Findings and Conclusions of the State District Court, reprinted in Jurisdictional Statement app. at 43a).

92. The Court agreed with Idaho and ASARCO that interest and capital gains income ASARCO received from the out-of-state payors should be treated in the same manner as the dividend income: "One must look principally at the underlying activity, not at the form of investment, to determine the propriety of apportionability." $102 \mathrm{~S}$. Ct. at 3116 (quoting Mobil Oil Corp. v. Commissioner of Taxes, 445 U.S. 425, 440 (1980)).

93. 102 S. Ct. at $3110,3111,3115,3116$ n.24. 
tion that the due process clause bars the apportionment of income from intangibles when the business activities of the payor "have nothing to do with the activities of the recipient in the taxing State."94 But emphasizing these phrases does not invest them with content. In analyzing the facts, the Court did little more than state them and pronounce its conclusion. Indeed, the Court took pains to make clear that its decision was rooted in the particular facts of the case before it.95 While one can derive some guidance for the future from the Court's discussion of the facts, ${ }^{96}$ the Court's approach in $A S A R C O$ seems to invite an endless stream of litigation over the requisite flow of goods, services, personnel and so forth, that are necessary to constitute a unitary business.

Second, the relationship in ASARCO between the facts the Court found to be dispositive and the factual premises underlying the losing party's position produces an odd sense of déjà $v u$. In Mobil, it will be recalled, ${ }^{97}$ the taxpayer never sought to demonstrate that it was not engaged in a unitary business with its subsidiaries, because of its belief that the issue was irrelevant to the case. The Court, of course, went on to rule against the taxpayer, hinging its decision on the existence of such a unitary business. In $A S A R C O$, Idaho conceded that the out-of-state payors "were not engaged in a single unitary business together with ASARCO"98 and instead devoted its energies to showing that ASARCO's acquisition, management, and disposition of the intangibles were related to ASARCO's own unitary business in the state. The Court, of course, went on to rule against the state, hinging its decision on the absence of a unitary business between the out-of-state payors and the in-state payee. In both Mobil and $A S A R C O$, then, we have the anomalous situation in which the losing party never challenged the critical factual predicate underlying the Court's holding, even though the predicate itself was far from incontrovertible..$^{99}$

Third, the dissent leveled a number of criticisms at the Court's view of both the law and the facts of the case which deserve brief mention. It took issue with the Court's refusal to consider ASARCO's relationship to its investments as part of ASARCO's uni-

94. 102 S. Ct. at 3110 (emphasis omitted); $102 \mathrm{~S}$. Ct. at 3115 ; see $102 \mathrm{~S}$. Ct. at 3116 n.24.

95. 102 S. Ct. at 3115 n.22, 3116 n.24.

96. See text at note 164 infra.

97. See text at note 17 supra.

98. Brief for Appellee at 29.

99. See 102 S. Ct. at 3117-24 (O'Connor, J., dissenting); Mobil Oil Corp. v. Commissioner of Taxes, 445 U.S. 425, 460 (1980) (Stevens, J., dissenting). 
tary business, claiming that the Court in so doing had shrunk the unitary business concept reflected in Mobil and Exxon "beyond all recognition."100 Moreover, the dissent accused the Court of erring "even in its fundamental determination that ASARCO's holdings were passive investments unrelated to ASARCO's operational business."101 Where the majority found no significant managerial control by ASARCO of its subsidiaries and little significant interchange of products, the dissent found that ASARCO "had effective operational control of at least three of the five subsidiaries," 102 and that ASARCO's majority interest in Southern Peru Copper "evidently helped to assure ASARCO of supplies of unrefined copper, since $35 \%$ of the entire copper output of Southern Peru was sold to ASARCO.""103 While it may be a matter of small moment, except to the parties, whether the majority or the dissent more accurately portrayed the record, the considerable sparring in the opinions over the proper perception of the facts and their constitutional implications ${ }^{104}$ enhances the probability that the battle lines of future unitary business controversies will be drawn over such factual issues. Finally, the dissent expressed its dismay over its vision of the discordant consequences of the Court's decision in a discussion that is more notable for its novelty than its persuasiveness. ${ }^{105}$

\section{The Supreme Court's Opinion in Woolworth}

Following on the heels of $A S A R C O$, the Supreme Court's opinion in Woolworth reinforced $A S A R C O$ 's essential lessons. In holding that New Mexico lacked the power under the due process clause

100. $102 \mathrm{~S}$. Ct. at 3123 (O'Connor, J., dissenting). The dissent would have concluded that ASARCO had failed to prove either that its investment decisionmaking was not part of its unitary nonferrous metals business or that its investments were not part of the management of the financial requirements of that business. $102 \mathrm{~S}$. Ct. at 3118-22 (O'Connor, J., dissenting).

101. 102 S. Ct. at 3121 (O'Connor, J., dissenting).

102. 102 S. Ct. at 3121 (O'Connor, J., dissenting).

103. $102 \mathrm{~S}$. Ct. at 3123 (O'Connor, J., dissenting).

104. Compare 102 S. Ct. at 3113-16 \& nn.21-24 with $102 \mathrm{~S}$. Ct. at 3118-23 (O'Connor, J., dissenting).

105. Thus, in suggesting a variety of imaginary horribles that might emanate from the Court's decision, the dissent confuses principles developed under the Court's commerce clause jurisprudence, which preclude states from imposing a multiple tax burden on interstate business, see Hellerstein, supra note 1, at 130-37, with principles of due process, which permit the states to tax income satisfying the minimum nexus and rational relation requirements, even though this may result in double taxation. See Hellerstein, Some Reflections on the State Taxation of a Nonresident's Personal Income, 72 Mick. L. REv. 1309, 1310 (1974). The dissent's concern that the Court's decision will hamstring Congress in devising a legislative solution to state division-of-income problems pursuant to its commerce power is out of touch with the Court's views regarding the scope of congressional power under the commerce clause. See, eg., Hodel v. Virginia Surface Mining \& Reclamation Assn., 452 U.S. 264, 275-83 (1981); Moorman Mfg. Co. v. Bair, 437 U.S. 267, 280 (1978). 
to include Woolworth's dividends in its apportionable tax base, the Court reiterated that the "linchpin of apportionability' for state income taxation of an interstate enterprise is the 'unitary-business principle." "106 It likewise reaffirmed that the fundamental inquiry into the unitary business issue for purposes of determining the apportionability of income from intangibles received by a nondomiciliary parent from an out-of-state payor depends on the "underlying unity" 107 between the payor's and payee's business activities, not on whether "the non-domiciliary parent derives some economic benefit - as it virtually always will - from its ownership of stock in another corporation."108 The Court chided New Mexico, as it had chided Idaho, for advancing a definition of a unitary business that would, in the Court's view, emasculate the concept:

The state court's reasoning would trivialize this due process limitation by holding it satisfied if the income in question "adds to the riches of the corporation . ..." Income, from whatever source, always is a "business advantage" to a corporation. Our cases demand more. 109

Finally, the Court emphasized in Woolworth, as it had in ASARCO, that potential as distinguished from actual control of the out-of-state payor by the in-state payee does not suffice to establish a unitary business relationship between them. ${ }^{110}$

Although Woolworth thus added little to the constitutional doctrine enunciated in $A S A R C O$, the Court's application of this doctrine to the facts in the case is more illuminating than its rather conclusory factual analysis in $A S A R C O$. The Court observed in Woolworth that it had stressed three "factors of profitability"111 in Mobil that arise from the "operation of a business as a whole"112 and which "evidence the operation of a unitary business":113 "functional integration, centralization of management, and economies of scale." "114 Though implicit in its opinion in $A S A R C O$, the Court

106. F. W. Woolworth Co. v. Taxation and Revenue Dept., 102 S. Ct. 3128, 3134 (quoting ASARCO Inc. v. Idaho State Tax Commn., 102 S. Ct. 3103, 3110 (1982)).

107. 102 S. Ct. at 3135 (quoting Mobil Oil Corp. v. Commissioner of Taxes, 445 U.S. 425, $440(1980))$.

108. $102 \mathrm{~S}$. Ct. at 3135.

109. $102 \mathrm{~S}$. Ct. at 3135 (citation omitted).

110. $102 \mathrm{~S}$. Ct. at 3135-38; see text at note 86 supra.

111. 102 S. Ct. at 3135 (quoting Mobil Oil Corp. v. Commissioner of Taxes, 445 U.S. 425 , 438 (1980)).

112. 102 S. Ct. at 3135 (quoting Mobil Oil Corp. v. Commissioner of Taxes, 445 U.S. 425, $438(1980))$.

113. $102 \mathrm{~S}$. Ct. at 3135 .

114. 102 S. Ct. at 3135 (quoting Mobil Oil Corp. v. Commissioner of Taxes, 445 U.S. 425 , $438(1980))$. 
now depicted these factors in bold relief and proceeded to examine the record in light of them.

In evaluating the relationship of Woolworth to its four dividendpaying subsidiaries (three of which were wholly owned ${ }^{115}$ ), the Court found little functional integration. Drawing a sharp distinction between the business of retailing, in which Woolworth and its subsidiaries exclusively engaged, and the vertically integrated petroleum enterprises it had considered in Mobil and Exxon, the Court pointed to evidence in the record indicating an absence of "centralized purchasing, manufacturing, or warehousing of merchandise;"116 autonomous decisionmaking by subsidiaries with respect to such matters as site selection, advertising, and accounting control;117 and independent responsibility by each subsidiary for obtaining financing. 118 While the New Mexico Supreme Court found that there was "some flow back and forth of goods" 19 between parent and subsidiaries, the Court rejected this observation as unsupported by the record. ${ }^{120}$ The Court therefore concluded that "the record is persuasive that Woolworth's operations were not functionally integrated with its subsidiaries."121

The Court similarly found little evidence of the existence of the two other unitary business factors, centralization of management and economies of scale. Each subsidiary operated as a distinct business enterprise at the management level; there was little interchange of personnel; each subsidiary enjoyed autonomy in retailing policy; and Woolworth had no formal organizational mechanism for overseeing the operations of its foreign subsidiaries. ${ }^{122}$ While there were some managerial links, the Court discounted them as insignificant when compared to the type of business integration it had encountered in Mobil and Exxon.123

Concluding that Woolworth and its four subsidiaries were therefore not engaged in a unitary business under the principles of Mobil, Exxon, and $A S A R C O$, the Court declared:

There is a critical distinction between a retail merchandising busi-

115. The other was 52.7 percent owned by Woolworth. See text at note 48 supra.

116. $102 \mathrm{~S}$. Ct. at 3136.

117. $102 \mathrm{~S}$. Ct. at 3135.

118. $102 \mathrm{~S}$. Ct. at 3136.

119. Taxation and Revenue Dept. v. F. W. Woolworth Co., 95 N.M. 519, 524, 624 P.2d 28, 33 (1981).

120. $102 \mathrm{~S}$. Ct. at $3136 \mathrm{n} .13$.

121. 102 S. Ct. at 3136.

122. $102 \mathrm{~S}$. Ct. at 3136-37.

123. $102 \mathrm{~S}$. Ct. at $3137-38$. 
ness as conducted by Woolworth and the type of multinational business - now so familiar - in which refined, processed, or manufactured products (or parts thereof) may be produced in one or more countries and marketed in various countries, often worldwide. In operations of this character there is a flow of international trade, often an interchange of personnel, and substantial mutual interdependence. The uncontradicted evidence demonstrates that Woolworth's international retail business is not comparable. There is no flow of international business. Nor is there any integration or unitary operation in the sense in which our cases consistently have used these terms. ${ }^{124}$

In addition to the dividends at issue, New Mexico had sought to include in Woolworth's apportionable tax base amounts that Woolworth was required to report as income on its federal income tax return in order to claim the benefit of a foreign tax credit for taxes paid by its dividend-paying subsidiaries. ${ }^{125}$ This so-called dividend "gross-up" is, in substance, the amount of foreign taxes paid by the foreign subsidiary which "is treated [for this purpose] as a dividend in the same manner as a dividend actually received by the domestic corporation from a foreign corporation."126 The Court summarily disposed of New Mexico's claims:

In this case the foreign tax credit arose from the taxation by foreign nations of Woolworth foreign subsidiaries that had no unitary business relationship with New Mexico. New Mexico's effort to tax this income "deemed received" - with respect to which New Mexico contributed nothing - must also be held to contravene the Due Process Clause. ${ }^{127}$

\section{State Income TaXation OF MultiJurisdictional CORPORATIONS AFTER ASARCO AND WOOLWORTH}

The evolution of constitutional standards governing state income taxation of multijurisdictional corporations suggests that $A S A R C O$ and Woolworth will have significant consequences beyond their narrow holdings. This Part explores the impact of $A S A R C O$ and $\mathrm{Wool}-$ worth on the scope of the unitary business concept, the construction of UDITPA, and the future of judicial intervention in conflicts over state income taxation of multijurisdictional businesses.

\section{A. The Scope of a Unitary Business}

The Court's decisions in $A S A R C O$ and Woolworth have visibly shaped the contours of the unitary business concept for purposes of

124. 102 S. Ct. at $3138-39$ (footnote omitted).

125. See note 48 supra.

126. H.R. ReP. No. 1447, 87th Cong., 2d Sess. A83 (1962), quoted in 102 S. Ct. at 3139.

127. 102 S. Ct. at 3139 (footnote omitted). 
determining the apportionability of income from intangibles. Although the Court purported merely to be applying familiar unitary business principles articulated in Mobil and Exxon, ${ }^{128}$ the facts in $A S A R C O$ and Woolworth required it to refine the guiding principles to resolve the unitary business issues that they raised. Whereas Mobil and its subsidiaries and Exxon's various functional departments were engaged in a unitary business under almost any plausible approach to the concept, ${ }^{129}$ neither ASARCO and its subsidiaries nor Woolworth and its subsidiaries presented the easy case of the vertically integrated business with a flow of goods, personnel, and services among its constituent parts. The Court had instead to delineate the limitations that the due process clause imposed on the apportionability of income from intangibles received by a nondomiciliary corporation from out-of-state subsidiaries with which it was not vertically integrated.

In analyzing the issue in terms of the underlying functional and managerial relationship between payor and payee, the Court expressly repudiated the sweeping unitary business definition offered by the states which would have encompassed intangibles that in any manner contribute to the economic benefit of the payee. ${ }^{130}$ The Court was fully justified in thus narrowing the unitary business concept. If the due process requirement of a "minimum connection" 131 between the state and the income it may tax is to have any meaning at all in this context, surely it must preclude taxation of the investment income that a nondomiciliary corporation receives, when the only connection between the taxing state and the income is that the corporation is a little bit richer for having received it. If this is all the Court meant to say in ASARCO and Woolworth, we can only stand back and applaud.

But the Court's opinions appear to go considerably further in narrowing the unitary business definition for purposes of determining the apportionability of income from intangibles. By focusing exclusively on the payor-payee relationship and denigrating a definition embracing the use of the intangibles in the payee's own unitary business, the Court's opinions at least by implication cast doubt on the power of a state to include in a nondomiciliary payee's apportionable tax base any income from intangibles received from

128. See ASARCO Inc. v. Idaho State Tax Commn., 102 S. Ct. 3103, 3114 n.22, 3116 n.24 (1982).

129. See Hellerstein, supra note 1 , at 148-51.

130. See text at notes 70-71 supra.

131. Miller Bros. v. Maryland, 347 U.S. 340, $344-45$ (1954). 
an out-of-state payor with which the payee is not conducting a unitary business. ${ }^{132}$

If this was what the Court meant to say in ASARCO and Woolworth, its opinions are objectionable on several grounds. First, it is difficult to comprehend why the "minimal connection between . . . [interstate] activities and the taxing State,"133 which is all the due process clause requires at this stage of the inquiry, ${ }^{134}$ should be translated through the unitary business principle into a requirement of an operational connection between the out-of-state and the instate enterprise for purposes of including income from intangibles in the nondomiciliary payee's apportionable tax base. Such a restrictive view of the "definite link"135 necessary to satisfy due process strictures does not comport with the wide latitude the Court has generally accorded the states when the exercise of their taxing power is challenged for lack of nexus. ${ }^{136}$

Second, sound considerations of policy do not warrant such a view. While the Court may properly have rejected as overbroad the states' definition of a unitary business, there are less sweeping approaches, short of a requirement of functional integration and the like, that would retain in a nondomiciliary payee's apportionable tax base income from intangibles with which the state can legitimately claim a palpable connection. It has been suggested, for instance, that there are "a variety of situations in which dividends ought clearly to be apportionable, both as a matter of due process of law and tax policy, even though they are paid by corporations that are not part of the taxpayer's unitary business conducted in the State."'137 It will be instructive to examine some examples of income from intangibles that arguably should be apportionable, even though received from a payor not functionally integrated with or actively controlled by the payee, to raise the question whether a unitary business concept defined by such criteria is defensible.

Income from short-term investments of working capital and

132. See notes 72-77 supra and accompanying text.

133. Moorman Mfg. Co. v. Bair, 437 U.S. 267, 273 (1978) (citation omitted).

134. See notes 62-63 supra and accompanying text.

135. Miller Bros. v. Maryland, 347 U.S. 340, 344-45 (1954).

136. See Hellerstein, Constitutional Limitations on State Tax Exportation, 1982 A.B.F. RES. J. 1, 19-20.

137. Hellerstein, Allocation and Apportionment of Dividends and the Delineation of the Unitary Business, 14 TAX NoTES 155, 159 (1982). [The ambiguities of Bluebook form may lead the reader to believe that Professor Walter Hellerstein wrote this piece. While the other citations to "Hellerstein" in this Article are to works by Walter Hellerstein, the work cited here was written by Jerome R. Hellerstein, Walter Hellerstein's father. - Ed.]. 
other current funds held for ordinary operating uses has generally been held to be apportionable without any requirement of functional integration between payor and payee. ${ }^{138}$ The rationale for including such income in the payee's apportionable tax base is that it is an integral part of the payee's unitary business carried on in part within the taxing state. ${ }^{139}$ While the Court disparaged this rationale in $A S A R C O, 140$ even ASARCO did "not contes[t] Idaho's right to treat interest income from temporary deposits of [its] working capital funds as apportionable business income derived in the ordinary course of [its] Unitary Business activities." 141 There are, to be sure, compelling reasons for excluding from a payee's apportionable tax base income from intangibles having "nothing to do with the activities"142 of the payee in the taxing state. Income from temporary investments employed in the ordinary course of the recipient's operations in the taxing state, however, would hardly seem to fall within the proscription. Yet a unitary business principle rooted in the concept of functional integration of payor and payee or active control of the former by the latter would in many cases preclude apportionability of such income.

Income from intangibles falling within the Supreme Court's Corn Products $^{143}$ doctrine represents another category of income which often would not be apportionable under a unitary business definition focused exclusively on the functional or managerial relationship between payor and payee. There is, however, a persuasive case for holding such income apportionable. ${ }^{144}$ In Corn Products Refining Co. v. Commissioner ${ }^{145}$ the Supreme Court held that the gains and losses incurred by a manufacturer of corn products from its purchase and sale of corn futures gave rise to ordinary income and losses rather than to capital gains and losses because the purchases and

138. See, e.g., Sperry and Hutchinson Co. v. Department of Revenue, 270 Or. 329, 527 P.2d 729 (1974).

139. See, e.g. , Montgomery Ward \& Co. v. Commissioner of Taxation, 276 Minn. 479, 151 N.W.2d 294 (1967).

140. $102 \mathrm{~S}$. Ct. at 3114.

141. Brief for Appellant at 26.

142. Mobil Oil Corp. v. Commissioner of Taxes, 445 U.S. 425, 442 (1980); see text at note 13 supra.

143. Corn Prods. Ref. Co. v. Commissioner, 350 U.S. 46 (1955).

144. See Hellerstein, supra note 137, at 159. Idaho did not refer to the Corn Products doctrine in its brief. New Mexico did cite Corn Products in its brief, but only in connection with the apportionability of Woolworth's foreign exchange gain. See Brief for Appellee at 34, Woolworth. The Court declined to consider New Mexico's treatment of this item, however, because the "matter was not considered below. $102 \mathrm{~S}$. Ct. at $3139-40$ n.26; see note 48 supra. 145. 350 U.S. 46 (1955). 
sales constituted an "integral part of its manufacturing business"146 rather than "transactions in property which are not the normal source of business income." 147 Thus ordinary income or deductions rather than capital gains or losses have been found in cases involving sale of stock acquired to insure a source of supplies, ${ }^{148}$ stock acquired to obtain or protect a job, fees, or commissions, ${ }^{149}$ and stock acquired to gain needed technology and personnel. ${ }^{150}$ The rationale for these holdings is that the gains or losses arise from the ordinary conduct of the taxpayer's business rather than from transactions in capital investments for which preferential tax treatment is granted. By analogy, income from transactions integrally related to a taxpayer's business activities in a state should be includable in the recipient's apportionable tax base because it possesses the "minimum connection"151 with the taxpayer's activities in the state required by due process strictures. Such income has generally been held to be apportionable without any requirement of functional integration or centralized control of payor and payee. ${ }^{152}$ Yet the Court's opinions in $A S A R C O$ and Woolworth may be read to discredit these cases. ${ }^{153}$

One should not, of course, dismiss as idle the Supreme Court's concern that the unitary business concept would be "destroy[ed]" if it were interpreted to embrace the relationship between the business use of an intangible asset and the income recipient's business in the taxing state. ${ }^{154}$ Nevertheless, tying the unitary business definition to the underlying relationship of the payor's and payee's enterprises through functional integration, managerial control, or economies of

146. 350 U.S. at 51.

147. 350 U.S. at 52.

148. See, e.g., Booth Newspapers, Inc. v. United States, 303 F.2d 916 (Ct. Cl. 1962).

149. See, e.g., Steadman v. Commissioner, 424 F.2d 1 (6th Cir. 1970) (purchase by attorney of corporate client's stock to protect position as general counsel). 1971).

150. See, e.g., Schlumberger Technology Corp. v. United States, 443 F.2d 1115 (5th Cir.

151. Miller Bros. v. Maryland, 347 U.S. 340, 344-45 (1954).

152. See, e.g., W. R. Grace \& Co. v. Commissioner of Revenue, 378 Mass. 577, 583, 393 N.E.2d 330, 334 (1979) (citing Corn Products).

153. The Court's disparaging remarks in Woolworth concerning the significance of the hearing examiner's finding that Woolworth "had commingled its dividends with its general funds and had used them for general corporate operating purposes," F. W. Woolworth Co. v. Taxation and Revenue Dept., $102 \mathrm{~S}$. Ct. 3128, 3135 n.11 (1982), may be read as supporting this interpretation of the rule. The Court observed that

[t] his analysis . . . subverts the unitary business limitation. All dividend income - irrespective of whether it is generated by a "discrete business enterprise" - would become part of a unitary business if the test were whether the corporation commingled dividends from other corporations, whether subsidiaries or not.

$102 \mathrm{~S}$. Ct. at $3135 \mathrm{n.11}$ (emphasis in original) (citation omitted).

154. ASARCO Inc. v. Idaho State Tax Commn., 102 S. Ct. 3103, 3114 (1982). 
scale - is not an appropriate response. ${ }^{155}$ This approach is not compelled by the simple mandate of the due process clause that there be "some definite link, some minimum connection, between a state and the person, property, or transaction it seeks to tax."156 Nor is it consistent with the respect for state taxing authority that the Court has by and large accorded in this context. ${ }^{157}$ As for the problem of drawing the line between intangibles that are and that are not sufficiently related to the taxpayer's business in the state to justify inclusion of the income therefrom in the payee's apportionable tax base, "the great body of the law consists in drawing such lines . . .,"158 and "the fact that a line has to be drawn somewhere does not justify its being drawn anywhere."159 Indeed, as the Court in Mobil itself had to remind the taxpayer who was advancing a restrictive rule al-. locating income to a single situs to protect itself from possible abuses of a rule of apportionment, the "argument underestimates the power of this Court to correct excessive taxation . . . ."160

Having said all this, we should recall that the preceding discussion has assumed that the Court actually intended to inject a requirement of functional integration and centralized management into its definition of a unitary business for purposes of including income from intangibles in a nondomiciliary payee's apportionable tax base. ${ }^{161}$ This is a plausible reading of the Court's opinion. ${ }^{162}$ It is not, however, the only reading it may be given, a fact that may render the preceding discussion more than academic. After all, the

155. It might be noted, however, that a unitary business concept focusing exclusively on the underlying relationship of the payor to the payee would clearly be appropriate for purposes of determining whether the state may require a group of corporations to file a combined report for income tax purposes. See Hellerstein, supra note 1, at 121-30. In such cases, the essential question is whether the state may treat the group of corporations as a single entity, not whether particular items of income are includable in the apportionable tax base. Indeed, under the combined approach, dividends, interest, and the like paid by one member of the combined group to another member of the group are eliminated entirely from the calculation of the group's combined income, which is determined by reference to income derived by members of the group from dealings with nonmembers of the group. See id.; Keesling \& Warren, The Unitary Concept in the Allocation of Income, 12 Hastings L.J. 42, 59-60 (1960). In $A S A R C O$ and Woolworth, however, the unitary business issues before the Court were concerned solely with the separate company approach to state corporate income taxation. Sce Hellerstein, supra note 1, at 123-24. The Court will, however, soon have an opportunity to confront the unitary business issues that arise in connection with the combined approach. See note 214 infra.

156. Miller Bros. v. Maryland, 347 U.S. 340, 344-45 (1954).

157. See Hellerstein, supra note 1.

158. Schlesinger v. Wisconsin, 270 U.S. 230, 241 (1926) (Holmes, J., dissenting).

159. Pearce v. Commissioner, 315 U.S. 543, 558 (1942) (Frankfurter, J., dissenting).

160. Mobil Oil Corp. v. Commissioner of Taxes, 445 U.S. 425, 447 (1980).

161. See text at note 77 supra.

162. See text at notes 72-76 supra. 
Court, at least according to its understanding of the facts, ${ }^{163}$ was dealing neither with income from short term investments used in the taxpayer's operations in the state, nor with income falling within the Corn Products doctrine, and the Court is not known for deciding issues not before it. If the Court did not intend to limit the definition of a unitary business along these lines, it should say so explicitly at the next appropriate opportunity.

Beyond narrowing the unitary business principle to some yet-tobe determined extent, the Court provided it with additional content, although not as much as one might have desired. We now know, for example, that functional integration, centralization of management, and economies of scale are key factors in determining whether there is a unitary or discrete business enterprise; that ownership by itself, regardless of its extent, does not make one business unitary with another; that potential as distinguished from actual managerial control will not justify a finding of unity; that a flow of products, personnel, and services among entities evidences the existence of a unitary business and the lack thereof evidences its absence; and that the interchange of some goods and the maintenance of some managerial links between entities will not inexorably lead to the conclusion that they are unitary. ${ }^{164}$ Whether this "guidance" will actually calm the waters in this troubled area, however, is another question that is considered below. ${ }^{165}$

Finally, as the Court emphasized in Woolworth and ASARCO, the scope of a unitary business, while delineated by general principles, is ultimately defined by particular facts of particular cases. "[T] he application of the unitary-business principle requires in each case a careful examination both of the way in which the corporate enterprise is structured and operates, and of the relationship with the taxing state."166 The Court's insistence that "these cases are decided on their facts in light of established general principles" 167 cannot, to be sure, obscure its confrontation and resolution of critical doctrinal issues in the course of reaching its decisions. Still, the Court's approach to the unitary business issue in ASARCO and Woolworth, with its painstaking scrutiny of the record, leaves one with the sense that whatever the broad principles to which it pays homage, the unitary business in the end may simply be something that the Court

163. See text at notes 79-81 supra.

164. See text at notes 79-92 \& 107-20 supra.

165. See text at notes 204-08 infra.

166. Woolworth, $102 \mathrm{~S}$. Ct. at 3138 n.22.

167. $A S A R C O, 102$ S. Ct. at 3116 n.24. 
knows when it sees it. ${ }^{168}$ Like other protean concepts with which the Court has had to grapple, the unitary business principle may therefore elude definition with intellectually satisfying precision.

\section{B. The Uniform Division of Income for Tax Purposes Act (UDITPA)}

As noted at the outset of this Article, ${ }^{169}$ the constitutional issues considered by the Court in $A S A R C O$ and Woolworth closely tracked the state statutory issues that arose under UDITPA in the state administrative and judicial proceedings. The question of the apportionability of ASARCO's and Woolworth's income under UDITPA depended on whether it was business income, which meant income arising from transactions and activity in the regular course of the taxpayer's trade or business and includes income from tangible and intangible property if the acquisition, management, and disposition of the property constitute integral parts of the taxpayer's regular trade or business operations. ${ }^{170}$

In the state proceedings, it will be recalled, ${ }^{171}$ the lower courts concluded that the disputed income was nonbusiness income allocable to the taxpayer's commercial domicile. The state supreme courts reversed these decisions and held that the income was business income apportionable in part to the nondomiciliary state in which the taxpayer was doing business. When the United States Supreme Court ruled that the due process clause forbade Idaho and New Mexico from including the disputed income in ASARCO's and Woolworth's apportionable tax bases, it effectively overturned the state court determinations that such income was business income under UDITPA. ${ }^{172}$

Needless to say, it is not novel doctrine that state law must yield to federal constitutional imperatives. Hence there would ordinarily be little justification in pursuing a question of state law that raised a definitively adjudicated federal constitutional issue except, perhaps, to observe that its future application must conform to the federal mandate. There are, however, at least two reasons why UDITPA's

168. Cf. Jacobellis v. Ohio, 378 U.S. 184, 197 (1964) (Stewart, J., concurring) (discussing pornography).

169. See text following note 45 supra.

170. UDITPA § 1(a). UDITPA's approach to dividing the income of a multijurisdictional business is considered more fully in the text at notes 6-7 \& 26-31 supra.

171. See text at notes $41-42 \& 52$ supra.

172. Of course, it did not actually hold that the income in question was therefore nonbusiness income allocable to the state designated by UDITPA. See UDITPA $\$ \S 1(\mathrm{e}), 4-8$; text at notes 17 \& $26-31$ supra. 
business/nonbusiness income distinction warrants some further comment. First, since UDITPA is in force in most of the states with corporate income taxes, its construction has unusually broad significance when compared to the typical state statute. Second, the Court's implicit gloss on UDITPA's business/nonbusiness income distinction represents a major defeat for the Multistate Tax Commission, which in recent years has been advancing, with considerable success, its expansive views of apportionability through its interpretation and administration of UDITPA. ${ }^{173}$

In order to avoid constitutional difficulties, state courts and administrative agencies charged with the responsibility of distinguishing business from nonbusiness income under UDITPA will presumably construe the distinction consistently with the principles articulated by the Supreme Court in $A S A R C O$ and Woolworth. Although the language of UDITPA plainly embraces a payee-focused approach to apportionable business income - "income from . . . intangible property if the acquisition, management, and disposition of the property constitute integral parts of the taxpayer's regular trade or business"174 - this is precisely the approach that the Court disapproved in ASARCO and Woolworth. One would anticipate, at a minimum, that state courts and agencies will interpret the business income concept as not including income from intangibles merely because they "contribute to or relate to or are in some way in furtherance of the taxpayer's own trade or business"175 or because they "ad[d] to the riches of the corporation." 176 When these are the only grounds asserted for classification of income from intangibles as business income under UDITPA, one would expect state courts and agencies to hold that the income was nonbusiness income specifically allocable to the commercial domicile or other state designated by UDITPA. ${ }^{177}$ With respect to income from intangibles that is more closely connected to the day-to-day operations of the taxpayer's business, such as income from working capital and income falling within the Corn Products doctrine, we are more likely to find state courts and agencies giving the UDITPA business income definition its natural reading and holding that such income is apportionable. State courts and agencies will not, in my judgment, ignore statutory

173. See note 37 supra.

174. UDITPA § 1(a).

175. ASARCO Inc. v. Idaho State Tax Commn., 102 S. Ct. 3103, 3114 (1982) (quoting Transcript of Oral Argument at 25).

176. F. W. Woolworth Co. v. Taxation and Revenue Dept., 102 S. Ct. 3128, 3135 (1982) (quoting Wallace v. Hines, 253 U.S. 66, 70 (1920)).

177. UDITPA $\S \S 1(e), 4-8$. 
language, abandon precedents, ${ }^{178}$ and disregard sound considerations of policy ${ }^{179}$ unless and until they receive more definitive instruction from the Supreme Court to do so.

The Multistate Tax Commission, which has been the driving force behind expansive interpretations of UDITPA's business income definition, will likewise have to make some adjustments in its approach, if not in its rhetoric. Both Idaho and New Mexico, after all, had adopted the MTC's regulations, which took the most generous view of dividends that fell within UDITPA's definition of apportionable business income, namely, dividends

where the stock with respect to which the dividends are received arises out of or was acquired in the regular course of the taxpayer's trade or business operations or where the purpose for acquiring and holding the stock is related to or incidental to such trade or business operations. 180

The Supreme Court flatly repudiated this approach to apportionability.

Spokesmen for the MTC will also have to trim their extravagant assertions that the path to clearing up confusion in this area lies in "treating all corporate income as apportionable business income."181 Flush from a string of victories ${ }^{182}$ in the Supreme Court ${ }^{183}$ and in state tribunals, ${ }^{184}$ the MTC anticipated further success in $A S A R C O$ and Woolworth ${ }^{185}$ but must now confront reality and undertake the task of revising its policy and rewriting its regulations to bring its interpretation of UDITPA into line with constitutional limitations.

178. See notes $138-39 \& 152$ supra and accompanying text.

179. See text at notes 137-52 supra.

180. Multistate Tax Commission Regulation IV.25(4), reprinted in ST. \& Loc. TAX SERV. (P-H) (All States Unit) I 6130, at 6104-05 (1973) (emphasis added); Idaho Income Tax Regulations 27.IV.1(c)(4), reprinted in ST. \& Loc. TAX SERV. (P-H) (Idaho) II 11,676-H.55, at 11,624 (1974); New Mexico Income Tax Regulations IT Reg. 17(b)(4), reprinted in ST. \& Loc. TAx SERV. (P-H) (New Mexico) If 11,212.20, at 11,204 (1974).

181. Dexter, Taxation of Income From Intangibles of Multistate-Multinational Corporations, 29 VAND. L. REv. 401,407 (1976). The author was and still is General Counsel to the MTC. See also Dexter, Tax Apportionment of the Income of a Unitary Business: An Examination of Mobil Oil Corp. v. Commissioner of Taxes of Vermont, 1981 B.Y.U. L. REv. 107; Corrigan, Mobil-izing Interstate Taxation, 15 TAX Notes 803 (1981). The author of the last article cited was and still is Executive Director of the MTC.

182. Except for those cases involving its own authority, see, e.g., United States Steel Corp. v. Multistate Tax Commn., 434 U.S. 452 (1978), the MTC has technically been involved in the cases cited in notes 183-84 infro only as an amicus curiae.

183. Exxon Corp. v. Wisconsin Dept. of Revenue, 447 U.S. 207 (1980); Mobil Oil Corp. v. Commissioner of Taxes, 445 U.S. 425 (1980); Moorman Mfg. Co. v. Bair, 437 U.S. 267 (1978); United States Steel Corp. v. Multistate Tax Commn., 434 U.S. 452 (1978).

184. See, e.g., Qualls v. Montgomery Ward \& Co., 266 Ark. 207, 585 S.W.2d 18 (1979); Atlantic Richfield Co. v. Dolan, 198 Colo. 413, 601 P.2d 628 (1979); Corning Glass Works v. Department of Revenue, 616 S.W.2d 789 (Ky. Ct. App. 1981).

185. Dexter, Post-Oral-Argument Comments on ASARCO and Woolworth, 15 TAX Notes 867,871 (1982). 
While the MTC's General Counsel predicted that if the taxpayers prevailed in ASARCO and Woolworth "the state corporate income tax system, which is dependent upon the unitary business principle, would be left in a shambles," 186 what he really meant was that the MTC's view of the unitary business principle would be left in a shambles. The state corporate income tax system will survive the Court's decisions limiting state tax authority just as interstate business has survived the Court's decisions expanding it ${ }^{187}$ in the face of taxpayers' dire predictions of its imminent demise. ${ }^{188}$

\section{The Court's Role in Adjudicating Controversies over State Income Taxation of Multijurisdictional Corporations}

Beyond the matter of how the latest turn in precedent or twist in doctrine will affect the principles of adjudication in this area, the Court's decisions in ASARCO and Woolworth raise more fundamental questions about the Court's perception of its own role in resolving controversies over state income taxation of multijurisdictional corporations. For a number of years now, the Court's opinions addressed to state division-of-income problems have generally reflected a hands-off attitude toward exercises of state tax power. ${ }^{189}$ Its recent decisions appeared to reaffirm this attitude. The Court displayed a remarkably relaxed view of its role in policing constitutional challenges to state division-of-income rules in its 1978 opinion in Moorman Manufacturing Co. v. Bair, ${ }^{190}$ which sustained Iowa's singlefactor sales formula for apportioning net income. In upholding over due process and commerce clause objections the very formula it had harshly criticized thirteen years earlier when invalidating the District of Columbia's apportionment provision on statutory grounds, ${ }^{191}$ the Court stressed the broad leeway the states enjoy in their choice and implementation of apportionment formulas as well as its own narrow function in reviewing them. It declared that "a formula-produced assessment will only be disturbed when the taxpayer has

186. Id. at 867.

187. See, e.g., Northwestern States Portland Cement Co. v. Minnesota, 358 U.S. 450 (1959).

188. See, eg., State Taxation on Interstate Commerce: Hearings Before the Senate Select Comm. on Small Business, 86th Cong., 1st Sess. pts. 1 \& 2 passim (1959) (reacting to the Supreme Court's opinion in Northwestern States Portland Cement Co. v. Minnesota, 358 U.S. 450 (1959)).

189. See Hellerstein, supra note 1 , at 115.

190. 437 U.S. 267 (1978). Moorman is discussed in Hellerstein, supra note 1, at 132-35, $143-44,146-48$.

191. General Motors Corp. v. District of Columbia, 380 U.S. 553 (1965). 
proved by 'clear and cogent evidence' that the income attributed to the State is in fact 'out of all appropriate proportion to the business transacted . . . in that State,' or has 'led to a grossly distorted result." "192 The Court also observed that even if a taxpayer could demonstrate that the interaction of two apportionment formulas subjected it to duplicative taxation, no issue of constitutional magnitude would be raised because the Constitution did not require the states to adopt uniform rules for the division of a multijurisdictional firm's income. ${ }^{193}$ Finally, the Court urged taxpayers unhappy with the consequences of its noninterventionist approach to seek relief from Congress rather than the Court. ${ }^{194}$

These themes - wide latitude for the states in dividing the income of a multijurisdictional enterprise, self-restraint by the Court in overseeing state initiatives for dealing with this task, and deference to Congress as the appropriate body for drawing definitive guidelines in this domain - firmly underpinned the Court's decisions two years later in Mobil and Exxon. ${ }^{195}$ In the course of its opinions in these cases, the Court stressed the freedom the states enjoyed in apportioning a multijurisdictional corporation's income "in order to obtain a 'rough approximation' of the corporate income that is 'reasonably related to the activities conducted within the taxing State" "; 196 it emphasized that its own role was confined to assuring that the corporation's tax liability was not "out of all appropriate proportion to the business transacted by the [taxpayer] in th[e] State"; 197 and it adverted to the preemptive role that Congress might play in providing uniform rules governing division of income among

192. 437 U.S. at 274 (citations omitted).

193. 437 U.S. at $277-80$.

194. 437 U.S. at 280.

195. There was an intervening decision after Moorman and before Mobil and Exxon that might have been read as embodying a more vigilant attitude toward state division-of-income problems than that reflected in Moorman, Mobil, and Exxon. In Japan Line, Ltd. v. County of Los Angeles, 441 U.S. 434 (1979), the Court struck down a local property tax on Japanese cargo containers whose full value had already been taxed in Japan. The Court held that a state lacks power under the commerce clause to impose even a fairly apportioned, nondiscriminatory property tax upon foreign-owned and foreign-based instrumentalities of foreign commerce used exclusively in furtherance of such commerce. In Mobil, however, the Court gave Japan Line a narrow reading, noting, among other things, that the case was concerned with the division of a property-tax base as distinguished from an income-tax base and that it was concerned solely with foreign commerce, where the constitutional rules governing state taxation differ from the rules governing state taxation of interstate commerce. Mobil Oil Corp. v. Commissioner of Taxes, 445 U.S. 425, 448 (1980). Japan Line is discussed in Hellerstein, supra note 1 , at 137-39.

196. Exxon Corp. v. Department of Revenue, 447 U.S. 207, 223 (1980) (quoting Moorman, 437 U.S. at 273).

197. Mobil Oil Corp. v. Commissioner of Taxes, 445 U.S. 425, 437 (1980) (quoting Hans Rees' Sons v. North Carolina ex rel. Maxwell, 283 U.S. 123, 135 (1931)). 
the states. 198

As the preceding discussion has indicated, the Court's opinions in $A S A R C O$ and Woolworth reflect a strikingly different judicial perspective on state division-of-income issues. No longer are we told that the essential question is whether the state's apportionment formula has produced a "grossly distorted result"199 or one "out of all appropriate proportion to the business transacted ... in th[e] State." 200 Instead of a detached judicial tolerance for inferences a state is "entitled" to draw from the record, 201 we find the Court immersing itself in the factual details of the state administrative proceedings and rejecting state court inferences with which it disagrees. ${ }^{202}$ One aspect of the Exxon and Woolworth decisions dramatically illustrates the contrasting approaches between the two sets of cases. In Exxon, the Court relied upon the fact that Exxon's Wisconsin taxable income was merely 0.22 percent of the total company net income as compared to the 0.41 percent of its sales in the state in order to justify the conclusion that the Wisconsin levy was not "out of all appropriate proportion to business transacted ... in that State."203 In Woolworth; the Court paid no attention to a similar comparison which showed that Woolworth's New Mexico taxable income was 0.46 percent of the total company net income as compared to the 0.52 percent of its sales in the state. ${ }^{204}$

One could, perhaps, explain the difference in the Court's approach in cases like Moorman, Mobil, and Exxon, on the one hand, and $A S A R C O$ and Woolworth, on the other, by distinguishing between the issues of fair apportionment and apportionability. In Moorman, Mobil, and Exxon, it might be contended, the Court was dealing with businesses that were easily found (or assumed ${ }^{205}$ ) to be unitary, and the Court's permissive attitude was limited to the fairness of the apportionment of clearly apportionable unitary business income. In $A S A R C O$ and Woolworth, by contrast, the critical question was whether there was a unitary business whose income could

198. Mobil Oil Corp. v. Commissioner of Taxes, 445 U.S. 425, 448-49 (1980).

199. Norfolk \& Western Ry. v. Missouri State Tax Commn., 390 U.S. 317, 326 (1968).

200. Hans Rees' Sons v. North Carolina ex rel. Maxwell, 283 U.S. 123, 135 (1931).

201. See Mobil Oil Corp. v. Commissioner of Taxes, 445 U.S. 425,439 (1980).

202. See text at notes 119-20 supra.

203. Exxon Corp. v. Department of Revenue, 447 U.S. 207, 227 (1980) (quoting Hans Rees' Sons v. North Carolina ex rel. Maxwell, 283 U.S. 123, 135 (1931)).

204. Brief for Appellee at 5 n.10, F. W. Woolworth Co. v. Taxation and Revenue Dept., 102 S. Ct. 3128 (1982).

205. In Moorman, it was never suggested that the income at issue was not derived from a unitary business conducted in part in the taxing state, and the Court plainly assumed that Moorman's income was derived from a unitary business. 
constitutionally be apportioned at all. The Court had not, it might be suggested, ever taken a particularly indulgent approach to this issue in part because it had rarely had occasion to address any hard cases raising it. This explanation, however, fails to account adequately for the unmistakable contrasts in the two sets of cases between the Court's tone, its willingness to scrutinize the states' view of the facts, and its desire to defer the matters at issue to congressional resolution.

In any event, whatever the scope of $A S A R C O$ 's and Woolworth's implications, they reflect an attitude of judicial vigilance uncharacteristic of the Court's recent opinions in this area. The Court's posture in these cases may well have two significant institutional consequences. First, as intimated above, ${ }^{206}$ the Court's preoccupation with the facts in $A S A R C O$ and Woolworth is likely to generate a flood of litigation over the definition of a unitary business. Although the Court has provided us with some guidance in this area, a little knowledge is a dangerous thing. Thus while we know that "a continuous flow and interchange of common products" are "essential factors" in the unitary business definition, ${ }^{207}$ we also know that a flow of goods of up to 35 percent of a company's output was insufficient to bring it within the definition. ${ }^{208}$ There will soon be cases raising the question whether 40 or 45 or 50 percent is sufficient, especially in view of other distinguishing features of future cases that will no doubt be brought to light. While we know that "one or several common directors" and "irregular in-person" contacts between the management of a parent and its subsidiaries do not suffice to make their relationship a unitary one, ${ }^{209}$ suppose there are a majority of common directors and more frequent in-person contacts. The Court's abandonment of its catholic approach to the unitary business concept ${ }^{210}$ in favor of a narrower approach emphasizing the particular facts of the case is virtually certain to create an outpouring of litigation, some of which will inevitably end up in its own lap.

Second, the Court's decisions in $A S A R C O$ and Woolworth will probably undermine efforts to forge a legislative solution to state division-of-income problems. After all, the Court's decisions in cases like Moorman, Mobil, and Exxon provided the stimulus for renewed

206. See text at notes 95-96 supra.

207. ASARCO Inc. v. Idaho State Tax Commn., 102 S. Ct. 3103, 3116 n.24 (1982).

208. 102 S. Ct. at 3112. (1982).

209. F. W. Woolworth Co. v. Taxation and Revenue Dept., 102 S. Ct. 3128, 3137-38

210. See Hellerstein, supra note 1, at 148-51. 
congressional interest in these questions. ${ }^{211}$ The historical record in this area, moreover, suggests that an expansive Supreme Court decision supplies a necessary impetus to the enactment of legislation the very mention of which evokes immediate and vigorous opposition by states seeking to avoid any federal statutory restraint on their taxing authority. ${ }^{212}$ Despite the recent call by the General Accounting Office, a nonpartisan arm of Congress, for congressional intervention in this field, ${ }^{213} A S A R C O$ and Woolworth may, at least for the moment, ${ }^{214}$ lull Congress into the belief that the Court is actively engaged in the task of overseeing and, when necessary, curbing the states' endeavors to divide the income of multijurisdictional corporations.

\section{CONCLUSION}

The first installment of this Article concluded by observing that "[i]n Mobil and Exxon, state taxing authorities took on two of the nation's three largest industrial corporations and emerged from the judicial arena with resounding victories."215 It suggested that the Court had reaffirmed the states' broad power to tax multijurisdictional business, had underscored its own limited role in keeping that power within constitutional bounds, and had consequently made congressional intervention in this area more likely. In $A S A R C O$ and Woolworth, by contrast, the Court unequivocally rebuffed state taxing authorities in their efforts to tax two of the nation's other large enterprises. ${ }^{216}$ The doctrine articulated by the Court in its latest attempts to delineate the constitutional restraints on the states' power to tax a multijurisdictional corporation's income has refined in im-

211. See id. at 154-71.

212. See id. at 115.

213. General Accounting Office, Key Issues Affecting State TaXation of MulTUURISDICTIONAL CORPORATE INCOME NEED RESOlving (1982) (Report to the Chairman, House Comm. on Ways and Means).

214. As this Article went to press, the Court was considering two cases involving state taxation of multijurisdictional corporations' income. Caterpillar Tractor Co. v. Lenckos, 84 Ill. 2d 102, 417 N.E.2d 1343 (1981), prob. juris. noted, 102 S. Ct. 564 (1981), restored to calendar for reargument, 102 S. Ct. 2032 (1982); Container Corp. of America v. Franchise Tax Bd., 117 Cal. App. 3d 988, 173 Cal. Rptr. 121 (1981), prob. juris. noted, 102 S. Ct. 2034 (1982). In both cases, taxpayers are challenging the states' power to require the filing of a combined report. See notes 38 \& 155 supra and sources cited therein. Since the constitutional predicate to filing a combined report is the existence of a unitary business between the taxpaying corporation and its subsidiaries or affiliates, see note 155 supra, the Court will have an opportunity to clarify its views on a number of the matters discussed here.

215. Hellerstein, supra note 1 , at 171.

216. ASARCO was the nation's 234th largest industrial corporation in 1981. See ForTUNE, May 3, 1982, at 268. Woolworth was the nation's sixth largest retailer in 1981. See FORTUNE, July 12, 1982, at 140. 
portant respects the permissive approach reflected in Mobil and Exxon. More significantly, the Court's opinions in $A S A R C O$ and Woolworth bespeak a more active role for the Court than it has previously played in scrutinizing state division-of-income methods. If the Court's most recent opinions accurately measure its willingness to police state corporate income taxation, it will soon find a steady diet of these cases on its docket and may well remove the incentive for Congress to legislate in this domain. 